\title{
145. Langzeitbehandlung mit Somatostatin bei der Ulcusblutung des Risikopatienten
}

\author{
P. Mattes, S. Raptis, Th. Heil und H. Rasche \\ Department für Chirurgie der Universität Ulm, Abteilung I (Leiter: Prof. Dr. Ch. Herfarth)
}

\section{Extended Somatostatin Treatment of High-Risk Patients with Bleeding Ulcer}

Summarx. The results of continuous 50- to 67-h somatostatin infusion in 5 patients with bleeding ulcer are reported. Somatostatin treatment led to immediate cessation of the bleeding after $1 \mathrm{~h}$ in 3 patients with fresh gastric ulcer, while in 2 patients with callous gastric ulcer somatostatin was ineffective. Gastric secretion and gastrin were both significantly inhibited by somatostatin. There was no evidence, from laboratory investigations of hemostatic defects or hemorrhagic diathesis in the patients.

Key words: Somatostatin - Ulcer, peptic - Hemorrhage.

Zusammenfassung. Es wird über die Ergebnisse einer 50-67stündigen Somatostatinbehandlung bei 5 Patienten mit einer Ulcusblutung berichtet. Bei 3 Patienten mit frischem Ulcus ventriculi führte die Somatostatinbehandlung innerhalb einer Stunde zum Stillstand der Blutung, bei 2 Patienten mit chronisch-callösem Ulcus sistierte die Blutung nicht. Magensaft und Gastrinsekretion wurden durch Somatostatin signifikant gehemmt. Die hämostasiologischen Untersuchungen ergaben keinen Gerinnungsdefekt oder vermehrte Blutungsneigung bei den Patienten.

Schliisselwörter: Somatostatin - Ulcus - Blutung.

\section{Noradrenalin und Vasopressin in der Therapie der akuten Gastrointestinalblutung}

\author{
W. Kreuzer, A. Keiler, G. Salem und J. Navratil \\ II. Chirurgische Universitätsklinik Wien
}

\section{The Use of Suprarenin and Vasopressin in the Treatment of Acute Gastrointestinal Bleeding}

Summary. Pharmacological control of acute hemorrhage from an esophageal varix by continuous intra-arterial infusion of vasopressin selectively into the superior mesenteric artery has proved to be efficient in avoiding emergency shunting procedures. Hemodynamic measurements revealed a significant 55 percent decrease in superior mesenteric artery flow and 43 percent fall in the elevated portal pressure. Local application of suprarenin by the intraperitoneal or the intragastric route is followed by a 60 percent decrease in portal vein flow and is shown to be of benefit in the treatment of arterial upper gastrointestinal bleeding. The general circulation was not seriously affected by either method.

Key words: Vasopressin - Suprarenin - Hemorrhage, acute upper gastrointestinal - Acute esophageal varix. 